\title{
Consumer Protection in Transnational Contexts
}

Jacques Delisle

Elizabeth Trujillo

Texas A\&M University School of Law, etrujillo@law.tamu.edu

Follow this and additional works at: https://scholarship.law.tamu.edu/facscholar

Part of the Law Commons

\section{Recommended Citation}

Jacques Delisle \& Elizabeth Trujillo, Consumer Protection in Transnational Contexts, 58 Am. J. Comp. L. 135 (2010).

Available at: https://scholarship.law.tamu.edu/facscholar/802

This Article is brought to you for free and open access by Texas A\&M Law Scholarship. It has been accepted for inclusion in Faculty Scholarship by an authorized administrator of Texas A\&M Law Scholarship. For more information, please contact aretteen@law.tamu.edu. 


\section{JACQUES DELISLE* AND ELIZABETH TRUJILLO**}

\section{Consumer Protection in Transnational Contexts $\dagger$}

This Article provides an overview of United States consumer protection law in the growing number cases with an international dimension that arise with economic globalization, expanding transnational corporations, worldwide production chains, manufacturing outsourcing and more efficient international communication. U.S. consumer protection law remains primarily state law, including tort and product liability law, contract and warranty law, and general and product-specific consumer protection statutes. (This refers to the private law remedies for consumer goods which are the substantive laws addressed in this article.) There is little treaty-based, constitutional or federal law except for federal regulatory law that largely adopts state law standards, requires disclosure or encourages disclosure, monitoring and attention to consumer safety. Parties have extensive discretion to choose fora and governing law. Where parties do not so choose (as in noncontractual relations), plaintiffs have significant but limited discretion to select fora, and ordinary U.S. choice of law rules apply for substantive law, possibly with a greater tendency to choose U.S. law. Requirements for personal jurisdiction are similar to those in domestic litigation. Recognition and enforcement of foreign judgments depends partly on compliance with treaty obligations and application of relatively uniform state laws' procedural and substantive standards. Class action litigation and alternative dispute resolution are available. In recent years, U.S. authorities increasingly have pursued international agreements and cooperative arrangements to increase regulatory capacity, enforcement and harmonized standards. The impact of intergovernmental cooperation has been limited, and U.S. consumers face formidable hurdles in seeking remedies against foreign defendants. Defective exports from China illustrate these limits and the increasing liklihood of foreign-based dangers to U.S. consumers. U.S. litigation against U.S. (and occasionally Chi-

* Stephen A. Cozen Professor of Law and Director, Center for East Asian Studies, University of Pennsylvania. My thanks to Gabriela Femenia for her indispensible help with sources and to Catherine Struve, Kristen Madison, Curtis Reitz, and Kermit Roosevelt for their comments.

** Associate Professor, Suffolk University School of Law. My thanks to Greg Vanden-Eykel and Katie Nickerson for their invaluable research assistance.

$\dagger$ DOI 10.5131/ajcl.2009.0044. 
nese) defendants (many of which have foreign-based manufacturing facilities) shows how U.S. consumers can create incentives to pressure foreign producers to improve safety. Increased monitoring and regulatory harmonization may follow, benefiting U.S. consumers.

\section{General Framework}

\section{A. Constitutional Law}

Consumer protection law in the United States is primarily state law (much of which is based on model "uniform laws" such as the Uniform Commercial Code, is modeled on federal unfair and deceptive trade practices law, or targets specific sectors such as automobiles, real estate or consumer finance), federal legislation and regulations (including those of the Federal Trade Commission or other agencies with responsibility for consumer protection and product safety) and common law (including torts and contracts).

The U.S. Constitution does not specifically address consumer protection or rights. Some constitutional provisions are relevant to consumer protection, including in international transactions. The constitution grants Congress the power to make all laws "necessary and proper to carry out its enumerated powers" and to regulate foreign and domestic commerce. ${ }^{1}$ These provisions underpin federal consumer rights legislation, including the law creating the Federal Trade Commission (FTC) in 1914 to "prevent persons, partnerships, or corporations . . . from using unfair methods of competition in or affecting commerce and unfair or deceptive acts or practices in or affecting commerce."2 Although constitutional non-delegation doctrine imposes some limits on Congress's authority to assign discretionary power to administrative agencies, ${ }^{3}$ the FTC Act and legislation for other government entities with responsibilities relevant to consumer protection are within Congress's broad discretion. ${ }^{4}$

The due process clauses ${ }^{5}$ impose limits-albeit loose ones-on consumers' ability to sue foreign defendants in federal and state courts. (See Section II.) U.S. Supreme Court decisions have established constitutional limits-albeit expansive and somewhat

1. See U.S. Const. Art. I, § 8, cls. 3, 18.

2. 15 U.S.C. $\$ 45$ (2006)

3. See generally, Alfred C. Aman, Jr. and William T. Mayton, Administrative LAw 9-36 (2nd ed 2001). See also, A.L.A. Schechter Poultry Corp. v. United States, 295 U.S. 495 (1935); Panama Refining Co. v. Ryan, 293 U.S. 388 (1935); United States v. Rock Royal Co-op, Inc. 307 U.S. 533 (1939); Yakus v. United States, 321 U.S. 414 (1944); cf. National Broadcasting Company v. U.S. 319 U.S. 190 (1943).

4. Sears, Roebuck \& Co. v. Fed. Trade Comm'n, 258 F. 307, 310-12 (7th Cir. 1919) (Congress may define and declare unlawful unfair or deceptive competition in commerce); TC Hurst \& Son v. Fed. Trade Comm'n, 268 F.874, 877-78 (E. D. Va. 1920) (declaring Federal Trade Commission constitutional).

5. U.S. Const. Amts. V, XIV. 
uncertain ones-on "grossly excessive" awards. 6 The First Amendment to the U.S. Constitution protects "commercial speech." Although this protection is limited and false or deceptive advertisements do not fall within its rationale (which focuses on the role of providing information in the marketplace), the constitutional principle arguably imposes limits on lawmakers' and regulators' power to prohibit practices and content in, and to provide civil remedies for, advertisements, including deceptive advertisements that are a significant focus of consumer protection laws.

\section{B. International and Supranational Rules}

The United States is not a party to any international agreements that specifically address consumer protection. The United States participated in the abandoned effort to craft international rules for Internet transactions. The United States has engaged in Organization of American States efforts to develop draft conventions on consumer protection, primarily concerning choice of law, jurisdiction, and dispute resolution (including support for intergovernmental cooperation and electronic arbitration and other informal forms of dispute resolution). ${ }^{8}$ The United States also has participated in more informal multilateral organizations and processes and bilateral efforts to enhance cross-border cooperation and to improve the quality of consumer protection regimes. (See Sections V-VI.)

International principles and norms, especially from European Union law, have influenced critiques and reform proposals in debates over U.S. consumer protection law, but with little clear impact on U.S. law. 9

Some international agreements to which the United States is a party have implications for consumer protection. Examples include World Trade Organization (WTO) rules governing public health and safety-based measures affecting trade and other agreements the

6. BMW of North America v. Gore, 517 U.S. 559 (1996).

7. See generally Virginia State Bd. of Pharmacy v. Virginia Citizens Consumer Council, Inc., 425 U.S. 748 (1976).

8. See Hal Burman, Private International Law, 43 INT'L LAw. 741, 746-748 (2009); David P. Stewart, Private International Law: A Developing and Dynamic Field, 30 U. PA. J. INT'L L. 1121, 1128-30 (2009); cf. Norbert Reich, Transnational Consumer Law-Reality or Fiction? 27 PENN. ST. InT'L L. Rev. 859 (2009).

9. See, e.g., New Frontiers of Consumer Protection: The InTerplay between Public and Private Enfrocement (Fabrizio Cafaggi \& Hans-W. Micklitz, eds. 2009); James J. Healy, Consumer Protection Choice of Law: European Lessons for the United States, 19 DukE. J. Comp. \& INT'L L. 535 (2009); Symeon C. Symeonides, The American Revolution and the European Evolution in Choice of Law, 82 TuL. L. REv. 1741 (2008); Andreas Maurer, Consumer Protection and Social Models of Continental and Anglo-American Contract Law, 14 InD. J. Global LEGal Stud. 252 (2007); Jennifer S. Martin, An Emerging Worldwide Standard for Protections of Consumers in the Sale of Goods, 41 Tex. INT'L L.J. 223 (2006); Luisa Antoniolli, Consumer Law as an Instance of the Law of Diversity, 30 VT. L. REV. 855 (2006); A. Brooke Overby, An Institutional Analysis of Consumer Law, 34 VAND. J. TRANSNAT'L L. 1219 (2001). 
United States has reached addressing trade and consumer protection. (See Sections II and VI.)

\section{JuRISDICTION AND JUDGMENT ENFORCEMENT}

\section{A. Personal Jurisdiction}

In most respects, U.S. law of personal jurisdiction for international consumer protection cases is the same as the law of personal jurisdiction generally. The plaintiff must establish that the defendant has "minimum contacts" with the forum jurisdiction, that the suit does not offend traditional notions of fair play and substantial justice (which are necessary to satisfy constitutional due process), and that the defendant falls within the reach of the state's "long arm statute" (which is often coextensive with the reach permitted by the constitution). Plaintiffs often bring consumer protection claims in state courts, which are courts of general jurisdiction. Federal courts relatively rarely have "federal question jurisdiction" because relatively little law giving rise to private claims in consumer protection cases is federal law. In international consumer protection cases, federal courts sometimes have "diversity jurisdiction," which extends to cases between United States and foreign nationals, but only where the amount in controversy exceeds $\$ 75,000 .{ }^{10}$

The requirement for "general jurisdiction" can be met by the defendant's having "continuous and systematic" contacts with the forum state and that it would not be unreasonable for the defendant to be sued there, even for claims not arising from those contacts. "Minimum contacts for specific jurisdiction" exist where the claim arises out of the defendant's contacts with the forum state. It is sufficient if the defendant "purposely availed" itself of the privilege of conducting activities in the forum state, thus enjoying the protection of its laws. ${ }^{11}$

These standards-particularly general jurisdiction-often are hard to meet in cases of consumer transactions involving foreign parties. Although specific jurisdiction typically is a very low threshold in consumer products cases, the Supreme Court has embraced an arguably higher standard where the defendant is a foreign party. ${ }^{12}$ In a

10. A federal court may take jurisdiction if a state court in the state where the federal court sits could take jurisdiction, if a federal statute authorizes jurisdiction, or if the claim arises under federal law and no state court has jurisdiction over the claim. Of course, jurisdictional limits imposed by the constitution and, in the first scenario, by state long arm statutes apply. FTC v. USA Beverages, No. 05-61682, 2005 U.S. Dist. LEXIS 39042 at *3-5 (S.D. Fla. Nov. 4, 2005); FED. R. Crv. P. 4(k).

11. See generally, International Shoe v. Washington, 326 U.S. 310 (1945); WorldWide Volkswagen Corp. v. Woodson, 444 U.S. 286, 297 (1980); Hanson v. Denckla, 357 U.S. 135 (1958); Burger King Corp. v. Rudzewicz, 471 U.S. 462 (1985).

12. Asahi Metal Industry Co., Ltd. v. Superior Court of California, Solano Co., 480 U.S. 102 (1987). 
plurality opinion, the Court found the minimum contacts standard was not met by a foreign component manufacturer's mere awareness that its products would be incorporated in finished goods reaching U.S. markets. (The Court majority found the exercise of jurisdiction under the circumstances to be unreasonable.) Still, commentators conclude that courts have found adequate in transnational cases connections of the same, limited sort that minimally suffice for interstate (that is, non-international) defendants. ${ }^{13}$

International consumer protection cases in the United States sometimes arise from online transactions. One leading case established a "sliding scale" test-adopted in many circuit courts of appeal (particularly for specific jurisdiction) - for Internet-based cases. This analysis uses a spectrum from jurisdiction-non-conferring "passive" and merely information-posting websites to jurisdiction-conferring interactive websites that exchange information and provide for conducting transactions. This test has been criticized as ill-fitting Internet reality. Some courts apply other standards, focusing on whether the defendant's Internet conduct "targeted" or had significant effects in the form state. Some courts simply apply the conventional purposeful availment and reasonableness tests in Internet cases. ${ }^{14}$

\section{B. Definition of Consumer}

Many jurisdictional issues arise due to features of substantive U.S. consumer protection and related laws, which reach broadly and often include foreign potential defendants. "Consumer" is defined relatively expansively in many laws; for example, as one who purchases a good primarily for personal, family, or household use. ${ }^{15}$ Subject matter-specific consumer protection laws (including those focusing on lending, real estate sales, and insurance) define consumers to include those who use such services. (See Section III.)

Warranty law permits recovery by some "remote purchasers" or "remote consumers"- those who do not directly purchase the good and are not in privity of contract with the seller. Federal warranty

13. See id. See also, Jennifer H. Doan \& Darby V. Doan, Satisfying Due Process in Obtaining Jurisdiction over the Foreign Component Manufacturer, 76 DEF. Couns. J. 145 (2009); Mark P. Chalos, Successfully Suing Foreign Manufacturers, 44-NOV TrIAL 32 (2008); Paul R. Dubinsky, Is Transnational Litigation a Distinct Field? 44 StAN. J. INT'L L. 301 (2008).

14. Zippo Mfg. Co. v. Zippo Dot Com, Inc., 952 F.Supp. 1119 (W.D. Pa. 1997); Life Alert Emergency Response, 2008 WL 5412431; See also ABA Section of Antitrust Law, Consumer Protection Law Developments 746-48 (2009); Anne S. Hornsby, Internet Transactions and Communications: Expanding or Contracting Traditional Notions of Personal Jurisdiction? 70 ALA. LAw. 378 (2009); Moritz Keller, Lessons for the Hague: Internet jurisdiction in contract and tort cases in the European Community and the United States, 23 J. Marshall J. CompuTER \& INFo. L. 1 (2004); Rio Properties, Inc. v. Rio Inter. Interlink, 284 F.3d 1007 (9th Cir. 2002).

15. UCC. $\S 1-201(12) ; 15$ U.S.C. $\$ 2301$ (1) (Magnusson-Moss Warranty Act). 
law (see Section III) extends covered warrantees to transferees, including any person to whom a warranty-covered product "is transferred during the duration of an implied warranty or written warranty." 16 The Uniform Commercial Code (UCC) (see Section III) ${ }^{17}$ provides three alternative formulations for those other than the immediate purchaser who may recover from the seller for injury resulting from a breach of warranty: the family, household members and guests of the buyer; 18 "any natural person who may be reasonably expected to use, consume or be affected by the goods; ${ }^{19}$ or "any person" injured by the seller's breach of warranty. ${ }^{20}$

Most states' tort law extends liability for defective products to all parties in the chain of manufacturers and sellers of consumer goods. Most states' general unfair and deceptive trade practices statutes, unlike the federal law on which many are modeled, provide for private rights of action by consumers (sometimes including corporations when acting as consumers) against those who engage in broadly defined unfair or deceptive trade practices, including many that can be undertaken by foreign defendants and defendants acting abroad. ${ }^{21}$ Operating through a U.S. subsidiary will not always insulate a foreign defendant from personal jurisdiction in a consumer protection case. U.S. courts will hold foreign parent entities amenable to jurisdiction under an "alter ego" theory if the parent entity exercises sufficiently extensive control over the U.S. subsidiary or the U.S. subsidiary is deemed to be an empty shell. ${ }^{22}$

\section{Forum Selection Clauses}

Forum selection clauses are permitted in international consumer transactions. U.S. Courts usually defer to parties' choice in contracts cases, with "unconscionability" or "unfairness" of forum selection

16. 15 U.S.C. $\S 2301(1)$.

17. UCC \& 2-318.

18. Twenty-nine states and the District of Columbia have adopted the first option. See U.C.C. $\$ 2-318$ (2008). Several states have extended it to third party beneficiaries other than family members such as employees. See e.g. Fl. Stat. s. $672.318(2004)$; McCarthy v. Florida Ladder Co., 295 So. 2d 707 (Fla. Dist. Crt. App. 1974); Quadrini v. Sikorsky Aircraft Div. 505 F. Supp. 1049 (D. Conn. 1981) (following official comments of Connecticut section 2-318 which did not intend to preclude everyone except family, household members, or guests); McNally v. Nicholson Manuf. Co., 313 A.2d 913 (Me 1973) (holding that employees may be members of "corporate family").

19. See Professional Lens Plan, Inc. v. Polaris Leasing Corp., 675 P.2d 887, 894 (Kan. 1984). Eight states have adopted the second option.

20. See AgGrow Oils, L.L.C. v. National Union Fire Ins. Co. of Pittsburgh, PA, 276 F. Supp. 2d 999, 1015 (D. N.D. 2003) (third party beneficiary assumes breach of warranty rights when contracting parties expressly intend so). Five states and the U.S. Virgin Islands have adopted the third option.

21. See also UCC \& 2-315.

22. See generally Allyson W. Haynes, The Short Arm of the Law, 64 U. MIAMI L. REv. 133, 159-161 (2009); Lonny Sheinkopf Hoffman, The Case Against Vicarious Jurisdiction, 152 U. PA. L. REv. 1023, 1043-1074 (2004). 
clauses being grounds for invalidation. Such clauses less commonly exist, and courts often view them more skeptically, in torts cases. ${ }^{23}$

In the absence of a valid forum selection clause, the consumer plaintiff remains, to a significant but not unlimited extent, master of his or her claim. The consumer may sue in any court that has jurisdiction. The defendant may be able to remove the case to federal court (including in those cases involving a foreign party for which a federal court would have diversity jurisdiction), or have the case dismissed on a forum non conveniens motion (often to a foreign defendant's home jurisdiction).

In U.S. law (which varies somewhat across federal and numerous state jurisdictions), a forum non conveniens motion turns on: (1) whether the foreign jurisdiction (a) is available (that is, courts are open to the plaintiffs' claims and defendants are amenable to suitmatters addressed by other jurisdictions' laws and international agreements, including in the Hague Convention on the Service Abroad of Judicial and Extrajudicial Documents in Civil and Commercial Matters); and (b) provides an adequate remedy (that is, the other jurisdiction's courts must: (i) apply substantive laws that provide some remedy for the type of claim brought by the plaintiffalthough the law of the alternative forum can satisfy this standard even though it may be less favorable to plaintiff than the law of plaintiff's chosen forum; and (ii) be sufficiently fair, competent, unbiased, and so on, that they do not deprive the plaintiff of meaningful justice); (2) "private interest" factors (relative ease of access to evidence; availability of compulsory process for, and relative cost of, obtaining participation of witnesses in the foreign jurisdiction; enforceability of a judgment rendered by the forum state; and so on); and (3) "public interest" factors (workload of the forum court; burden on forum state citizens of jury duty in a claim without strong connections to the forum; interests of the two jurisdictions in (a) litigating the claim and (b) avoiding complex questions of choice of law and application of foreign law by forum state court). ${ }^{24}$

While these factors in principle apply equally whether the "other" jurisdiction is another U.S. state or a foreign country, the inquiry is in practice often different. Assessments of private interest factors turn partly on whether the foreign state is party to the Hague Convention on the Taking of Evidence Abroad in Civil or Commercial

23. See generally Hannah L. Buxbaum, Forum Selection in International Contract Litigation, 12 WillametTe J. InT'L L. \& Disp. Resol. 185 (2004); Bremen v. Zapata Off-Shore Co., 407 U.S. 1 (1972); Carnival Cruise Line v. Shute, U.S. 499 U.S. 585 (1991); Symeonides, supra note 9, at 1769-71.

24. Piper Aircraft Co. v. Reyno, 454 U.S. 235 (1981); Gulf Oil Co. v. Gilbert, 330 U.S. 501 (1947); Sara J. Gourley and Tamar Kelber, Transnational Product Liability Problems, SK009 ALI-ABA 241 (2004). A defendant also can seek transfer of venue to another federal court. The analysis is similar to that applied in forum non conveniens cases. 
Matters, whether letters rogatory are possible, as well as features of domestic civil procedure law of the foreign forum. Jurisdictions where the neutrality and independence of courts or the sophistication of legal systems are objects of greater suspicion and doubt in the United States generally receive more probing scrutiny from U.S. courts. Yet, there is no clear pattern in courts' decisions to grant or deny forum non conveniens motions, including in tort and contract cases involving the same doctrinal issues that often arise in consumer protection cases.

In U.S. fora, international consumer protection cases (like transnational cases generally) can present special hurdles to plaintiffsones that are unevenly addressed by international agreements. Plaintiff must properly serve the defendant with process. For defendants present in the United States, this typically is not a major obstacle. For defendants abroad in jurisdictions that are parties to the Hague Convention on the Service Abroad of Judicial and Extrajudicial Documents in Civil and Commercial Matters, service must proceed in accordance with the convention's requirements, through the U.S.'s designated central authority and its counterpart in the foreign jurisdiction, or through direct service of process by a competent entity in the foreign jurisdiction. ${ }^{25}$ Discovery and access to evidence can pose additional challenges. Where a relevant foreign jurisdiction is party to the Hague Convention on the Taking of Evidence Abroad in Civil or Commercial Matters, the convention provides procedures. U.S. courts alternatively may follow the Federal Rules of Civil Procedure. ${ }^{26}$ Some foreign jurisdictions are not party to the Convention (or assert significant reservations), impose severe limitations on gathering evidence for use abroad or have enacted "blocking statutes" to protect their citizens from U.S. litigation, limiting the ability of a U.S. litigant to obtain information, witnesses, or documents abroad. ${ }^{27}$

\section{Recognition and Enforcement of Foreign Judgments}

United States law does not include specific provisions for recognition and enforcement of foreign judgments in consumer cases, nor

25. See Hague Services Convention arts. 3-6; AuguSt Horvath et AL, Consumer Protection Law Developments 742 (2009).

26. See Horvath, supra note 25, at 750. Courts most often use the Federal Rules of Civil Procedure. See Societé Industrielle Aerospatiale v. United States, 482 U.S. 522 (1987).

27. See id. at 751. States adopting full or partial blocking statutes include France, Australia, Belgium, Canada, South Africa, Germany, New Zealand, Belgium, Norway, Sweden, the United Kingdom, and several states in Latin America (which have adopted notably strong provisions denying their courts jurisdiction over cases initially brought in the United States). See, Rajeev Muttreja, How to Fix the Inconsistent Ap. plication of Forum non Conveniens Doctrine to Latin American Jurisdiction, 83 N.Y.U. L. REv. 1607 (2008); Walter W. Heiser, Forum non Conveniens and Retaliatory Legislation, 56 U. KAN. L. REv. 609 (2008). 
is there a clear distinction in practice concerning recognition of foreign judgments in consumer cases and other types of cases. The United States is a party to no general international agreement on the recognition of foreign judgments. In 2005, the United States supported the failed efforts to develop a Hague Convention on International Jurisdiction and Recognition and Enforcement of Foreign Judgments in Civil and Commercial Matters. The United States has no agreements specifically requiring mutual enforcement of judgments in civil cases. Some of the U.S.'s friendship, commerce and navigation treaties, and other subject-matter specific treaties with limited numbers of parties provide each party's nationals "equal access" to the other's courts or proscribe generally disqualifying the other party's courts' judgments in treaty-covered cases. The view that "equal access" clauses mandate enforcing non-U.S. courts' judgments on the same terms as sister U.S. states' judgments has been controversial and not uniformly accepted. More specific treaty provisions on judgment enforcement are very rare and limited. ${ }^{28}$ This absence of robust treaty-based obligations is variously attributed to U.S. reluctance to commit to enforcing foreign judgments and potential partners' wariness of undertaking possible obligations to enforce judgments reflecting U.S. laws that are internationally exotic (including, among matters relevant to consumer rights cases, high punitive damage awards or expansive strict product liability.)

Law governing recognition of foreign court judgments (including the Uniform Foreign Money Judgments Recognition Act adopted, with variations, in a majority of states) requires that the judgment be foreign, for a sum of money, final, conclusive and enforceable where rendered. The UFMJRA requires non-recognition where there was lack of due process (including impartiality), or personal jurisdiction or subject matter jurisdiction (factors that make a foreign judgment not "conclusive"). It permits non-enforcement for lack of notice, fraud, repugnance to the public policy of the enforcing state and several other factors (including the issuing court's having overridden parties' forum selection, the issuing court's being a seriously inconvenient forum, or the judgment's conflicting with other final and conclusive judgments). The Restatement (Second) of Conflict of Laws largely tracks the UFMJRA. Beyond the nearly absent treaty law and in the absence of applicable state law, broad principles of comity apply and

28. See Linda Silberman, Comparative Jurisdiction in the International Context: Will the Proposed Hague Judgments Convention Be Stalled?, 52 DePaul L. Rev. 319, 321 (2002); Jens Dammann and Henry Hansmann, Globalizing Commercial Litivation, 94 CoRNELl L. REv. 1, 44, n. 41 (2008) (discussing judicial and academic views of friendship, commerce and navigation treaties). See also U.S.-Australia Free Trade Agreement, Art. 14.6-14.7, available at http://www.ustr.gov/trade-agreements/freetrade-agreements/australian- $\mathrm{fta} /$ final-text (provisions committing each state not to disqualify money judgments issued by other state's courts in cross-border consumer protection cases covered by the agreement). 
U.S. courts look to the existence of foreign court jurisdiction, adequacy of judicial process, and reciprocity in enforcing U.S. judgments-although the modern trend is to follow the UFMJRA principle of not requiring reciprocity. ${ }^{29}$

Different levels of scrutiny and reluctance to enforce foreign judgments appear to reflect perceptions of the quality of law and judicial process in foreign jurisdictions that are not specific to consumer transactions. For example, judgments appear to be fairly routinely enforced when issued by courts in Western European states, ${ }^{30}$ but a recent case is believed to be the first in which a U.S. court has enforced a Chinese judgment awarding civil damages (specifically, under product liability law - an area of law applicable to many international consumer protection cases). ${ }^{31}$

\section{Choice of Law; U.S. Consumer Protection Law}

\section{A. Choice of Law}

United States law has no special rules governing choice of law in international consumer cases. Ordinary choice of law rules for torts, contracts and consumer transactions apply.

Common law tort law, including fraud, deceit and product liability law apply to some international consumer cases. In the United States, this is primarily state law. Since the "choice of law revolution" eroded the simple lex loci delicti rule, most U.S. states employ other tests, including: the Restatement (Second) of Conflict of Laws test, which applies the law of the place of conduct or place of injury, except where another state has a more significant interest; or "combined modern" multifactor approaches which typically emphasize the interests of relevant states in having their laws applied; or a "better law" standard. ${ }^{32}$ Empirical studies of recent trans-jurisdictional (but mostly intranational) torts have found that courts overwhelmingly apply the more pro-plaintiff law, heavily rely on the number and relevance of "contacts" of the tort and parties to the relevant states,

29. See Hilton v. Guyot, 159 U.S. 113 (1895); Restatement (Second) of Conflict of Laws $\S 98$ (1988); Restatement (Third) of Foreign Relations Law of the United States $\S \S 481-482(1987)$.

30. See generally Samuel P. Baumgartner, How Well Do U.S. Judgments Fare in Europe? 40 GEO. WASH. INT'L L. REv. 173, 174 (2008) (arguing that perceived asymmetry of strong U.S. enforcement of European judgments and weaker European enforcement of U.S. judgments is illusory because U.S. judgments fair better in European courts than is generally thought); $c f$. Mark D. Rosen, Should "Un-American" Foreign Judgments Be Enforced? 88 MINN. L. REv. 783 (2004) (previously routine U.S. enforcement of foreign judgments eroding as courts face more foreign judgments that conflict with U.S. legal norms).

31. Hubei Gezhouba Sanlian Industrial Co. Ltd. v. Robinson Helicopter Company Inc, 2009 WL 2190187 (C.D.Cal.).

32. Symoenides, supra note 9; Restatement (Second) of Conflict of Laws $\S \S 6,145$ 146 (1971); Alan Reed, The Anglo-American Revolution in Tort Choice of Law Principles, 18 Ariz. J. INT'L \& COMP. L. 867 (2001). 
usually apply the law of the forum, and show no strong pattern in choosing between the law of the place of conduct and the place of injury when those are different jurisdictions. ${ }^{33}$

Choice of law rules for contract cases generally allow parties much autonomy to choose the law governing their agreements and disputes. Under the Restatement standard that characterizes the law in many U.S. states, courts will invalidate parties' choice of law if they determine that the selected state lacks a "substantial relationship" to the parties or the transaction, or the selected laws violate the fundamental "public policy" of a state with a materially greater interest (often the forum state), the law of which would be applied in the absence of a forum selection clause ${ }^{34}$ Among the grounds for invalidation with special relevance for international consumer protection cases are, in some jurisdictions, parties' choice of laws that would invalidate the contract or, less often, invalidate a portion of the contract or uphold waivers of class action rights (including in consumer protection cases). ${ }^{35}$ Critical accounts find inconsistency and unpredictability in the application of rules limiting parties' discretion in choice of law. ${ }^{36}$

Under the UCC standard in effect in most states, parties can select the law of any state or nation that bears a "reasonable relation" to the transaction. ${ }^{37} \mathrm{~A}$ revision adopted in 2001, but not enacted by states and dropped from the UCC in 2008, limited parties' choice of law in consumer cases by requiring that application of the chosen law "not deprive" the consumer of the benefit of pro-consumer laws that relevant state law otherwise provides. ${ }^{38}$ Among the criticisms of the now-defunct revision was that it made online sellers potentially subject to the law of every jurisdiction in which they sold to consumers

33. Symeon C. Symeonides, Choice of Law in American Courts in 2008, 57 Am. J. Comp. L. 269 (2009); Symeonides, supra note 9; Symeon C. Symeonides, Choice of Law for Products Liability: The 1990s and Beyond, 78 TuL. L. REv. 1247 (2004).

34. Restatement (Second) of Conflicts of Laws $\$ \S 187-188$.

35. Symeonides, supra note 33, at 302-04.

36. Healy, supra note 9.

37. UCC § 1-301 \& cmt. 1 (2008); see also El Pollo Loco, SA de C.V. v. El Pollo Loco, Inc., 344 F. Supp. 2d 986, 988-89 (S.D. Tx. 2004) (permitting parties to choose law of particular nation to govern transaction so long as transaction bears reasonable relation to such nation); see also Seeman v. Philadelphia Warehouse Co., 274 U.S. 403,408 (1927) (setting forth "reasonable relation" test similar to UCC's and requiring parties to act in good faith and to choose jurisdiction that has "natural and vital connection" to transaction).

38. UCC § 1-105 (1977); UCC § 1-301(e) (2003), amended by UCC § 1-301 (2008). UCC \$ 1-301 also prohibits parties' choice of law where the UCC specifies the applicable law. This provision mostly covers types of transactions that generally do not generate international consumer protection cases. 
(notwithstanding choice of law clauses in their online agreements with consumers). ${ }^{39}$

The advent of online transactions-and the attendant increase in consumer cases to which laws of many national jurisdictions might apply-has brought attempts to develop new rules for international consumer protection cases. The Uniform Computer Information Transactions Act (UCITA)-adopted in a handful of U.S. jurisdictions-allows parties broad autonomy (much criticized by consumer groups) over choice of law and does not require a connection between the parties or the transaction and the chosen law's jurisdiction. Where otherwise lawful, e-commerce contract choice of law clauses still can face comparatively exacting scrutiny for unconscionability and other challenges to the enforceability of contracts of adhesion. ${ }^{40}$

In the absence of a valid choice of law provision, courts consider the place of the making, negotiation, performance, and subject matter of the contract and the domicile of the parties. ${ }^{41}$ The UCC permits the application of the law of any state or nation having an "appropriate" relation to the transaction. ${ }^{42}$

Consumer transactions that have international dimensions raise special choice of law and related issues that can significantly favor the application of U.S., rather than foreign, law. As noted earlier, complex tort choice of law rules lead to the consideration of many factors, including, on some analyses, a quest for the substantively "better law" and a tendency to favor application of the law of the plaintiff's home or chosen forum, at least where it is more favorable to his or her case.

A commonly raised concern about transnational consumer cases in U.S. courts (like much other litigation, especially tort litigation) is that plaintiffs forum shop, seeking the benefits not only of more sympathetic courts and favorable procedural rules, but also the forum jurisdiction's more favorable substantive law, which forum courts may be more likely to apply. While choice of law and choice of forum are conceptually distinct inquiries, U.S. courts' perceived preferences for applying familiar, local law may be more pronounced where the alternative to forum law is not the law of another jurisdiction within

39. See James J. White, Symposium: Out with the Old, In with the New?: Articles 2 and $2 A$ of the Uniform Commercial Code , 3 DePaul Bus. \& Comm. L.J. 519, 527 (2005).

40. See, e.g., Mo Zhang, Contractual Choice of Law in Contracts of Adhesion and Party Autonomy, 41 AKron L. REv. 123 (2008); Karen Alboukrek, Adapting to a New World of E-Commerce: The Need for Uniform Consumer Protection in the International Electronic Marketplace, 35 Geo. WASH. INT'L L. REv. 425 (2003) (discussing national-including FTC-and multinational-including OECD-attempts to frame standards for e-commerce cases); Fernand Piera, International Electronic Commerce, 10-SUM CURRENTS: INT'L TRADE L.J. 8 (2001).

41. Restatement (Second) of Conflict of Laws $\S \S 6,188$.

42. UCC § 1-301 cmt. 2 (2008). 
the United States but is, rather, the law of a truly foreign, often more legally dissimilar jurisdiction. ${ }^{43}$

When U.S. law governs a transnational consumer protection case, there are several potentially applicable sources of law. (The substantive law primarily discussed in this section is that which gives rise to private law remedies in cases involving consumer goods; other laws, not systematically addressed here, focus on transactions in services or provide for direct government safety regulation of producers or sellers.)

\section{B. Tort Law}

Common law tort actions sometimes remain available although they have been superseded in many respects by statutory actions. The common law tort of deceit is similar across U.S. jurisdictions although there is some variation in how the elements of the tort are interpreted, the defenses available, and the threshold for awarding punitive damages. Generally, a plaintiff must prove that a defendant has knowingly (or without sufficient basis to know) made a false representation of a material fact and intended to induce reliance by the plaintiff who did reasonably so rely and suffered damage as a result.

Product liability law varies somewhat more from state to state. Generally, manufacturers and sellers face: true strict liability for manufacturing defects; liability for design defects, under standards that range from a near-strict liability standard to a "reasonable consumer expectation" test to a negligence or near-negligence test that assesses trade-offs between the foreseeable risks of harm and the utility of product as designed (sometimes measured against a reasonable alternative design that would have prevented the harm); and a negligence standard for failure to provide adequate warnings or disclosure of a product's dangers. Defenses vary across jurisdictions, with many states' laws allowing a reduction of liability where the plaintiff is partly at fault. In transnational consumer cases, to the extent such tort liability extends to foreign defendants, it typically reaches manufactures of products or components, but it can also reach foreign sellers and trademark licensors. American courts have not accepted the argument, made by a handful of scholars, that the Alien Tort Statute (which provides for liability for torts committed "in violation of the law of nations" where the plaintiff is a non-U.S. na-

43. Such issues also arise in the context of forum non conveniens motions in transnational cases (including consumer protection cases) brought in the United States. Although such motions in principle involve choice of forum, not choice of law, several of the factors involved in most courts' tests are redolent of choice of law inquiries, and critics argue that courts often approach forum non conveniens questions as choice of law questions. See Section II; see also Elizabeth T. Lear, National Interests, Foreign Injuries, and Federal Froum Non Conveniens, 41 U.C. Davis L. REv. 559 (2007). 
tional) should extend to international consumer product liability cases. ${ }^{44}$

Tort law remedies in consumer cases include compensatory damages for harms suffered by defrauded consumers, destruction of property (other than the product itself) and physical injury and associated costs (including lost income, medical and related expenses and other such costs) and pain and suffering borne by consumers harmed by defective products. Punitive damages may be awarded where the defendant's behavior is judged especially egregious under standards that vary across jurisdictions but typically require that defendant have acted willfully, maliciously or with reckless disregard for the rights and interests of the plaintiff.

\section{UCC and Warranty Law}

Warranty law provides consumers with protections that generally extend to transnational transactions. Article 2 of the UCC includes elements of consumer protection (primarily in its warranty provisions) and is in effect, with minor variations, in forty-nine states. ${ }^{45}$ Article 2 of the UCC provides that sellers may create express warranties that the goods conform to: seller's affirmation of fact or promises (including in advertisements) relating to the goods; seller's description of the goods; or samples or models of the goodseven though terms "warranty" or "guarantee" are not used. ${ }^{46}$ Express warranties that appear with the product after sale (for example, in a manual contained inside the box) are enforceable even if the buyer was unaware of the warranties. ${ }^{47}$

Article 2 grants buyers, and imposes modest limits on sellers' ability to waive, certain implied warranties: the implied warranty of merchantability in sales with specified merchants (for which the waiver must mention "merchantability" and, if written, be "conspicuous"),48 and the implied warranty of fitness for a particular use for buyers relying (with seller's knowledge) on a seller's particular skill or judgment regarding the goods purchased.49 "Merchantability" is measured by several standards, including (among those most relevant to consumer transactions) the goods' fitness for the ordinary purposes for which such goods are used, and the goods' conformity to any promises or affirmations of fact on the container or label. ${ }^{50} \mathrm{An}$

44. See, e.g., Joel Slawotsky, International Product Liability Claims under the Alien Tort Claims Act, 16 Tul. J. INT'L \& CoMP. L. 157 (2007).

45. Louisiana is the exception, see LA. Civ. Code Art. 2438-2659 (1995).

46. U.C.C. \& 2-313(1)(a)-(c) (2002).

47. See Fire Insurance Exchange v. Electrolux Home Products, No. 05-70965, 2006 WL 2925286 (E.D. Mich 2006).

48. U.C.C. $\$ \S 2-314$ (1). It applies to merchants "with respect to goods of that kind." See also, U.C.C. \$ 2-104 (2002) (defining merchants).

49. U.C.C. $\$ \S 2-314(1), 315(2002)$.

50. U.C.C. \& $2-314(2002)$. 
implied warranty of fitness for a particular use arises when the seller "has reason to know any particular purpose for which the goods are required and that the buyer is relying on the seller's skill or judgment to select or furnish suitable goods." 51 A buyer must show actual reliance on the seller's particular knowledge, skill, or judgment. ${ }^{52}$

Some states' laws impose limits on exclusions or modification of UCC warranties for transactions in which the buyer is a consumer. ${ }^{53}$ UCC provisions and judicial decisions have developed definitions of unconscionable contract terms, unfair bargaining, good faith and fair dealing requirements, and doctrines governing contracts of adhesion (including shrink-wrap and click-wrap agreements) that offer protection to consumers (including in transnational transactions). ${ }^{54}$ Many U.S. courts have held that Article 2 governs consumer claims against manufacturers of trademarked durable goods who issue limited repair warranties even though there is no contract of sale between manufacturer and consumer. This rule potentially limits consumer remedies by requiring conformity to the UCC's requirement of "prompt notice" of nonconformity and the UCC's statute of limitations.

As remedies, the UCC permits consumers to reject or revoke defective goods (within a reasonable time and proper notice and, for revocation, only if the nonconformity substantially impairs value), sue for breach of warranty, recover damages, or secure rescission (including refunds). ${ }^{55}$ Although remedies thus vary, overall, the UCC sets forth remedies to compensate the buyer for the harm to his contractual interests caused by the seller's breach. ${ }^{56}$ The UCC does not provide punitive damages or relief for pain and suffering.

\section{Lemon Laws, etc.}

Product- or service-specific laws provide for consumer remedies that defendants cannot avoid through limitations or waivers of warranties. State "lemon laws," for example, impose warranty obligations to protect buyers of automobiles. ${ }^{57}$ Where defects in a vehicle are sufficiently serious and not reasonably repairable at seller's or manufacturer's expense, the buyer has a right to refund or replacement and, in many states, attorneys' fees and additional, statutory

51. See U.C.C. \& 2-315 (2002).

52. See id. at cmt; Outlook Windows Partnership v. York International Corporation, 112 F. Supp. 2 d 877 ( D. Neb.2000).

53. UCC §\& 2-314-2-316, 2-316A, 2-719.

54. See UCC $\S \S 1-203,1-201,2-103,2-302$; Restatement (Second) of Contracts $\$ 208$ (1981).

55. See UCC, §§ 2-601-608; 2-703-715. 2004).

56. See generally, E. Allan Farnsworth, Treatise on Contracts $\S 2.1$ (4th ed.

57. See National Consumer Law Center, The Practice of Consumer Law 9.2.3 (2d ed. 2006). 
damages. Proper defendants under some lemon laws include the manufacturer, which (compared to the dealer or others in the distribution chain) is probably more likely to be a foreign party.

\section{E. Federal Warranty Law}

The federal Magnuson-Moss Warranty Act (MMWA) ${ }^{58}$ primarily governs written warranties on consumer products, defined as "any tangible property which is distributed in commerce and which is normally used for personal, family, or household purposes."59 Although partly a statute that requires sellers to disclose conspicuously all terms and conditions of written warranties, the MMWA (along with FTC regulations under the MMWA) also sets minimum standards for written warranties generally and for those labeled as "full warranties."60 (Full warranties are rarely given.) The MMWA also regulates implied warranties on products that have express warranties, limiting modification of implied warranties on such products and permitting limitation of the duration of an implied warranty to that of the express warranty only if such limitation is reasonable, not unconscionable, and clearly and prominently set forth "on the face of the warranty." 61 In permitting recovery for breach of implied warranties, the MMWA looks mostly to state warranty laws, which often have more exacting privity requirements than the MMWA's broad provisions on express warranties (which extend to transferees of the original consumer purchaser).

The MMWA requires a seller to offer the consumer a choice of refund or replacement of defective goods covered by MMWA-governed full warranties if the good cannot be repaired in a reasonable number of attempts. The MMWA also provides for private rights of action to consumers for damages resulting from breach of MMWA-governed warranties to recover damages (including consequential damages unless limited by clear statement in the warranty), equitable relief, and reasonable legal costs. ${ }^{62}$

58. 15 U.S.C. $\S \S 2301-2312$.

59. 15 U.S.C. $\$ 2301(1)$.

60. 15 U.S.C. $\$ \S 2302(a)$ (disclosure goals); 2301(1) (terms to be disclosed include name and address of warrantors, identity of party to whom warranty is extended, products and parts covered, procedures for remedying defects, costs, exceptions, dispute settlement procedures, and legal remedies available to consumer); 2304 (written warranties must: disclose limitations on implied warranty and consequential damages; provide minimum remedy in reasonable time and without charge, and allow consumer to choose refund or replacement after reasonable attempts to remedy defect).

61. 15 U.S.C. § 2308 (1975).

62. 15 U.S.C. $\S 2304,2310$ (d). 


\section{F. State Unfair and Deceptive Trade Practices Law}

State unfair and deceptive trade practices laws offer consumers additional rights and remedies, including, in all but two states, a private right of action. ${ }^{63}$ Such laws typically establish a standard of "deceptive" that is more consumer-protecting than common law fraud and warranty. They generally do not require defendant's intent to deceive or, in most jurisdictions, plaintiff's justifiable reliance or, in some jurisdictions, proof of actual reliance, on defendant's material misrepresentation. State laws vary in scienter requirements for deception by omission and lists of specific deceptive trade practices. Most state laws also prohibit "unfair" or "unconscionable" trade practices, often defined as "offensive to public policy," "oppressive" toward consumers or "unscrupulous," and including unfair pricing, coercive sales practices and onerous dispute resolution clauses. State laws also include industry-or sector-specific provisions concerning unfair or deceptive practices. ${ }^{64}$

These state laws often allow recovery of minimum or multiple damages, damages for mental distress, pain and suffering, and consequential damages, rescission, or restitution. Many provide for attorneys' fees. Some state laws impose prerequisites to litigation, including demand on or notice to the defendant, a showing that the suit is in the "public interest" (a term with varying meaning across jurisdictions), or exhaustion of administrative remedies.

Examples from a few major states further illustrate the pattern of variation on common themes. Massachusetts law covers anyone who suffers harm from unfair methods of competition or unfair or deceptive acts in the conduct of any trade or commerce ${ }^{65}$ (including, by judicial interpretation, in online commerce). ${ }^{66}$ Texas law prohibits false, misleading, and deceptive business practices, unconscionable terms, and breaches of warranty, provided that the consumer sought to acquire goods or services by purchase or lease and those goods or services form the basis of the consumer plaintiff's complaint. ${ }^{67}$ Cali-

63. See Mary Dee Pridgen, Part B. State Law of Consumer Protection and Sales Practices, Chapter 6. Private Remedies, Consumer Protection and the Law § 6:2 (Sept. 2009). Iowa and North Dakota are the exceptions.

64. See generally, Dee Pridgen and Richard M. Alderman, Consumer Protection and THE LAW (2007); Mark E. Budnitz, The Federalization and Privatization of Public Consumer Protection Law in the United States, 24 GA. ST.U. L. REv. 663 (2008).

65. See M.G.L.A ch. 93A §§ 1-2 (1978).

66. See Waters v. EarthLink, Inc., 20 Mass. L. Rptr. 527 (2006) (plaintiff can bring class action suit under $93 \mathrm{~A}$ for inadequate internet service so long as he can prove defendant's unfair act caused his harm); Williams v. America Online, No. 000926,2001 WL 135825 at $* 1$ (Feb. 2001) (plaintiff can bring 93A claim for failure to provide promised Internet services).

67. V.T.C.A. Bus. \& C. $\$ 17.44$ (a); Service Corp. Int'l v. Aragon, 268 S.W. 3d 112, 117 (Tex. 2008) (consumer must have relationship with transaction to have standing); Brittan Comms. Int'l Corp. v. S.W. Bell Telephone Co., 313 F.3d 899, 907 (5th Cir. 2002) (setting forth framework for consumer protection standing analysis). 
fornia's Unfair Practices Act prohibits unfair, dishonest, deceptive, destructive, fraudulent, or discriminatory practices by which fair and honest competition is destroyed, but limits individual consumers to injunctive relief or restitution. ${ }^{68}$ Michigan's Consumer Protection Act bans unfair, unconscionable, or deceptive acts or practices in the conduct of trade or commerce. ${ }^{69}$ It authorizes consumers' individual and class action suits for equitable relief or damages ${ }^{70}$ and has been interpreted as extending consumer protection beyond ordinary tort law protections. ${ }^{71}$ Twelve states have adopted the Uniform Deceptive Trade Practices Act, which provides a cause of action for consumers suffering harm from misleading representations concerning goods and products or false and deceptive advertising or unfair and deceptive practices. ${ }^{72}$ Three states have adopted another similar uniform act, the Uniform Consumer Sales Practices Act, which provides similar protections for consumers. ${ }^{73}$

These state consumer protection laws track, to varying degrees, the principal federal legislation in the field. Most states' laws direct that interpretation of their consumer protection statutes be guided by FTC interpretations of the FTC Act. ${ }^{74}$ The FTC Act has been interpreted to extend to consumer transactions in foreign commerce.

\section{G. Federal Regulatory Law}

Regulatory statutes and the agencies that administer them create much of the law governing consumer transactions, including international ones, in the United States. Principal among these is the FTC Act (implemented by the FTC), which addresses broadly "unfair or deceptive acts or practices in or affecting commerce," including international commerce, with international e-commerce emerging as a focus in recent years. ${ }^{75}$ The scope of FTC authority is broad, extending to unfair practices "likely to cause substantial harm to consumers ... not reasonably avoidable by consumers . . . and not outweighed by countervailing benefits ...."76

68. See West's Ann. Cal. Bus. \& Prof Code $§ 17203$ (1977); West's Ann. Cal. Bus. \& Prof. Code $\$ 17001$ (1941).

69. See Мich. Сomp. Laws \$ 445.903-445.904(2008).

70. See id. at $\S 445.911$.

71. See Game On Ventures v. General RV Center, Inc., 587 F. Supp. 2d 831, 839 (E.D. Mich. 2008).

72. See National Conference of Commissioners on Uniform State Laws, Revised Uniform Deceptive Trade Practices Act (1966). The states adopting this act are: Colorado, Delaware, Georgia, Hawaii, Illinois, Maine, Minnesota, Nebraska, New Mexico, Ohio, Oklahoma, and Oregon.

73. These states are Kansas, Ohio and Utah.

74. M.G.L.A. ch. 93A at $\S 2$ (b); V.T.C.A. Bus. \& C. $\S 17.46(c)(1)(2007)$.

75. 15 U.S.C. $\S 45$. On extraterritorial application of 15 U.S.C. $\S 45$, see infra notes $92-95$

76. 15 U.S.C. $\S 45(n)$. 
As defined by the FTC, unfair practices include coercive or unscrupulous sales tactics, failure to disclose material information, and unfair contract clauses that exploit asymmetries in sellers' and consumers' power and information. 77 "Deception" includes, principally, deceptive advertising that overstates a product's quality and effects, misleading pricing, and inadequate disclosure of a product's dangers. ${ }^{78}$ The FTC ${ }^{79}$ along with other government agencies, also sets standards and guidelines for consumer protection in various sectors, including, among those most relevant to consumer protection in transnational cases, food, drugs, other manufactured consumer goods, autos, Internet marketing and electronic fund transfers. ${ }^{80}$

The FTC relies on rulemaking, investigation, and enforcement measures. FTC rulemaking gives consumers (and others) some ability to shape consumer protection law, through opportunities to comment on proposed rules, and to seek judicial review of final rules on the grounds that they are arbitrary, capricious, an abuse of agency discretion, promulgated in violation of applicable procedures, beyond statutory authority, or unconstitutional. ${ }^{81}$

FTC investigations and, in turn, enforcement actions may begin in response to complaints filed by consumers. ${ }^{82}$ If investigations do not resolve the matter (for example, by eliciting compliance or pledges of compliance from offenders), the FTC may pursue administrative enforcement ${ }^{83}$ or sue in federal court. ${ }^{84}$ FTC remedies include orders to offenders to provide affirmative disclosures (which have

77. See id. FTC policy statements that have guided FTC actions and influenced state laws include the FTC Policy Statement on Unfairness (December 17, 1980), later incorporated in an amendment to the FTC Act, 15 U.S.C. § 45(n).

78. FTC Policy Statement on Deception (Oct. 14, 1983). (The statement has been widely criticized as a retreat from prior, more pro-consumer standards).

79. The FTC undertakes much of this work through a Bureau of Consumer Protection, divided into seven divisions: Advertising Practices, Financial Practices, Privacy and Identity Protections, Marketing Practices, Enforcement, Planning and Information, and Consumer and Business Education.

80. See, e.g. 21 U.S.C $\$ 301$ et seq. ("Federal Food, Drug, and Cosmetic Act") (1938) (protecting consumers from harms due to falsely branded goods); 15 U.S.C. $\S 41$ et seq. ("Safe Web Act) (2006) (enhancing FTC authority to protect consumers from fraudulent online advertising and spam, especially focusing on international matters); Pub. L. No. 110-140, Energy Independence and Security Act of 2007 (2007) (protecting consumers from fraudulent energy efficiency labeling); 25 U.S.C. \&1693 ("Electronic Fund Transfer Act") (1980) (regulating consumers and businesses engaged in electronic fund transfers).

81. 15 U.S.C. $\$ 57 \mathrm{a}(\mathrm{e})(1)(\mathrm{A})$.

82. 15 U.S.C. $\$ \$ 41-58$, as amended (2006); 16 C.R.F. $\$ \S 2.1,2.2$. An FTC investigation may originate from (1) a request from the President, Congress, agencies, or the Attorney General; (2) referral from the courts; (3) complaints from members of the public; or (4) the Commission's own initiative.

83. 16 C.R.F. 53(b); 16 C.R.F. § 3.2.

84. FTC deceptive practices enforcement actions, unlike most of the state laws authorizing private remedies, do not require a showing of intent to deceive or actual deception. 
been important in health and safety cases) ${ }^{85}$ and cease and desist orders. ${ }^{86}$ In court, the FTC may seek preliminary or permanent injunctions, civil penalties (including for violations of cease and desist orders as well as for conduct violating the FTC Act and regulations), and more direct consumer redress including rescission, reformation, and refunds. ${ }^{87}$ Under the MMWA, the FTC or the U.S. Attorney General may bring suit against a warrantor for an injunction or temporary restraining order where a consumer has filed a complaint. ${ }^{88}$

Although the FTC does not pursue individual consumer complaints and the FTC Act does not create a private right of action, several of the remedies noted above do mandate relief to consumers. FTC actions more generally shape consumers' rights to relief in private actions because provisions in many states' laws direct that interpretation of the state's consumer protection law be guided by FTC or judicial interpretations of the FTC Act. State consumer protection laws often provide for FTC-like powers to pursue judicial enforcement, typically authorizing the state Attorney General to sue. ${ }^{89}$

The FTC's reach extends to unfair or deceptive practices in foreign commerce where those practices "are likely to cause reasonably foreseeable injury within the United States; or involve material conduct occurring within the United States."90 In transnational cases within this reach, the FTC can grant or pursue the same remedies as in domestic cases. ${ }^{91}$ Such extraterritorial reach has been repeatedly (although not unanimously) upheld by courts, which have found jurisdiction in cases involving overseas defendants and harms to American consumers and in cases involving activities in the United States and harms to consumers abroad.92 These cases may provide

85. See, e.g., Thompson Med. Co. v. FTC, 791 F.2d 189 (D.C. Cir. 1986) (advertising and packaging for 'Aspercreme' must disclose that product does not contain aspirin); Nat'l Comm'n on Egg Nutrition v. FTC, 570 F.2d 157, 164 (7th Cir. 1977) (association of egg producers must disclose that medical experts believe increased consumption of eggs may increase risk of heart disease); Figgie Int'l, 107 F.T.C. 313 (1986), affd 817 F.2d 102 (4th Cir. 1987) (unpublished opinion) (requiring disclosure that smoke detectors are superior to heat detectors).

86. 15 U.S.C. $\S \S 45,53$

87. 15 U.S.C. $\$ 53(\mathrm{~b}), 57 \mathrm{~b}(\mathrm{~b})$.

88. Id. at $2310(\mathrm{c})(1)$.

89. See, e.g., M.G.L.A. ch. 93A at $\S 2$ (b) (Massachusetts); Ann. Cal. Bus. \& Prof Code $\$ 17206$ (a)-(d) (California).

90. 15 U.S.C. $\$ 45(\mathrm{a})(3)(\mathrm{A}) \mathrm{i}-\mathrm{ii}(2006)$.

91. 15 U.S.C. $\$ 45(\mathrm{a})(4)(\mathrm{b})(2006)$.

92. See Michael A. Rabkin, When Consumer Fraud Crosses the International Line: The Basis for Extraterritorial Jurisdiction Under the FTC Act, 101 Nw. U. L. REv. 294, 296 (2007); Branch v. FTC, 141 F.2d 31 (7th Cir. 1944) (FTC authority to address actions in U.S. harming consumers abroad; competitors in the U.S. also harmed); FTC v. Magui Publishers, No. 91-54474, 1993 WL 430102, at 5 (9th Cir. Oct. 22, 1993) (French defendant violated FTC Act when participating in unfair and deceptive trade practices involving U.S. consumers); FTC v. Skybiz.com, 57 Fed. Appx. 374, 377 (10th 
additional support for state consumer protection laws' reach to cover activities and harms abroad given the provisions in many such laws directing that their interpretation be guided by interpretations of the FTC Act.

The U.S. SAFEWEB Act confirmed and expanded the FTC's authority to address cross-border online unfair and deceptive practices. Under the Act, the FTC may conduct investigations and discovery abroad (and collaborate with foreign authorities), and may address practices abroad that harm U.S. consumers and practices in the United States that cause consumer harms abroad. ${ }^{93}$

One aspect of the FTC's work has long focused specifically on international consumer protection issues: deceptive practices that misrepresent foreign-made goods as domestically produced. The issue had faded but returned with mid-1990s "Buy America" laws and the broader consumer sentiment that they partly reflected. ${ }^{94}$

Although the FTC looms especially large among government agencies with responsibilities for consumer protection (generally and, especially, in activities with an international element), other agencies are involved too and are vested with authority by subject matterspecific statutes. Covered areas include food and drug safety (under the Food and Drug Administration (FDA)), product safety (including imported products, under the Consumer Product Safety Commission (CPSC)), telemarketing (under the Federal Communications Commission), ${ }^{95}$ real estate advertising, sales and financing (under the Department of Housing and Urban Development), ${ }^{96}$ health insurance and medical privacy (under the Department of Health and Human Services) ${ }^{97}$ and consumer lending, debt collection and credit reporting (mostly under the FTC). ${ }^{98}$ With the exception of food, drug and consumer products, these areas of law are relatively peripheral to international consumer protection issues.

Cir. 2003) (U.S. seller affected commerce with foreign states and thus was under purview of FTC when marketing program to consumers abroad); FTC v. Commonwealth Mktg. Group, 72 F. Supp. 2d 530, 545 (W.D. Pa. 1999) (FTC Act language implies that the FTC has jurisdiction over some foreign deceptive and unfair practices); but see Niemann v. Dryclean USA Franchise Co., 178 F.3d 1126 (11th Cir. 1999) (absence of express congressional intent for FTC Act to reach extraterritorially establishes lack of extraterritorial application).

93. SAfe Web ACt, Pub. L. No. 109-455, 120 Stat. 3372 (2006).

94. See, e.g., Pridgen and Alderman, supra note 63, at 1001-1008.

95. Pub. L. No. 110-187, 122 Stat. 633 (2008).

96. 12 U.S.C. $\$ 2607$ (RESPA).

97. 45 C.F.R. 160 (HIPAA).

98. 15 U.S.C. 1601 et seq. (Truth in Lending Act); 15 U.S.C. § 1681 et seq. (Fair Credit Reporting Act); 15 U.S.C. \& 1692 et seq. (Fair Debt Collection Practices Act); 15 U.S.C. $\$ 1693$ (Electronic Fund Transfer Act). 


\section{H. Online Consumer Protection Laws and Policies}

U.S. laws and policies address consumer protection in online transactions, which are an increasingly important medium for international harms to consumers. The FTC receives complaints concerning online deceptive practices, as it does for other transactions. The Uniform Electronic Transactions Act and the federal Esign Act address consumer protection in online contexts, clarifying the application of traditional rules in the electronic commerce context, imposing disclosure requirements on sellers, and addressing problems of verification and consumer consent specific to the online environment. ${ }^{99}$ The FTC also has authority to regulate unfair or deceptive e-mail.

To address consumer harms from Internet scams, the FTC has issued a checklist to assist consumers in distinguishing between valid transactions and fraudulent or deceptive ones, including in "international e-commerce."100 The checklist provides guidelines for consumers to understand whether "the business you are buying from [is] 'consumer-friendly' for international e-commerce."101

The FTC's Fair Information Principles recommend that website operators provide consumers with an opportunity to access and dispute the accuracy and completeness of their personal information. ${ }^{102}$ Some state laws go further. California requires any commercial website or online service that collects personal information through the Internet to conspicuously post a privacy policy. ${ }^{103}$ At least fourteen states have anti-phishing acts to combat computer crime, identity theft, and unfair or deceptive commercial practices. ${ }^{104}$

The U.S. government and members of the technology industry operate Onguardonline.gov to provide practical tips to consumers,

99. Uniform Electronic Transactions Act, adopted in forty-seven states and the District of Columbia; Electronic Signatures in Global and National Commerce Act 15 U.S.C. § 7001 et seq. (2000).

100. See http://www.ftc.gov/bcp/edu/pubs/consumer/alerts/alt066.shtm. Considerations include understanding what kind of business the company engages in; where it is located; the product sold and its cost and currency used; information regarding transaction costs, warranties and delivery timelines; availability of safe payment options; consumer protections, including their accessibility, return policies, and opportunities to limiting sharing of consumer's personal information.

101. Id.

102. FTC, Privacy Online: A Report to Congress 7-8 (1998) available at http:// www.ftc.gov/reports/privacy3/priv-23a.pdf. Many states have adopted similar recommendations. See generally Horvath, supra note 25, at 77.

103. Cal. Bus. \& Prof. Code $\S 22575$ (a)-(b) (2005). Requirements include: the type of personal information collected by the website and categories of third parties with whom information is shared; the process available to a consumer to change personal information; and the process whereby the website operator notifies consumers who use the site of changes in the privacy policy. Id.

104. See id. at 108. These include Arizona, Arkansas, Connecticut, Minnesota, New Mexico, Rhode Island, Utah, Virginia, and Washington. Id. 
raise awareness, and guard against Internet fraud. ${ }^{105}$ Foci include cross-border scams, e-mail scams, online shopping, and reporting instructions for specific scams. ${ }^{106}$ Other federal and state entities maintain online consumer protection websites with policies and advice for protecting consumers in online transactions and interactions, including international ones.

\section{Alternative Dispute Resolution (ADR), Class Actions, Other Procedures}

\section{A. $A D R$}

Many U.S. jurisdictions consider arbitration clauses generally enforceable in consumer contracts. ${ }^{107}$ Traditionally, but decreasingly in recent years, arbitration clauses have been more frequently struck down in consumer contracts than in commercial contracts. Consumer cases are seen as raising greater problems of contracts of adhesion, bias against non-repeat, non-industry players, prohibitive costs (given ADR procedures' omission of the fee-shifting provisions available under some consumer rights litigation laws), and lack of probing appeal and review. On some views, many of these problems are worse still in international consumer arbitration (the awards from which are often in principle enforceable under the New York Convention, discussed below), where some of the protection some U.S. law affords consumers is absent. ${ }^{108}$

The MMWA encourages informal dispute resolution in warranty cases, permitting ADR clauses and providing that consumers who agree to $\mathrm{ADR}$ lose rights to litigate except to the extent that special legal provisions on class actions preserve such rights. The MMWA and FTC rules prescribe minimum requirements for cost, fair process and neutrality in ADR. ${ }^{109}$ MMWA ADR provisions have been controversial; some courts have construed the MMWA to uphold arbitration clauses that critics see as depriving consumers of fair process and adequate remedies. ${ }^{110}$

The United States is a party to the New York Convention on the Recognition and Enforcement of Foreign Arbitral Awards. The Con-

105. See http://www.onguardonline.gov/.

106. See http://www.onguardonline.gov/topics/cross-border-scams.aspx.

107. On litigation vs. ADR in consumer cases from a transnational and comparative perspective, see generally Geraint Howells and Rhoda James, Litigation in the Consumer Interest, 9 ILSA J. Int'l \& Comp. L. 1 (2002).

108. See, e.g., Donna M. Bates, A Consumer's Dream or a Pandora's Box: Is Arbitration a Viable Option for Cross-Border Consumer Disputes? 27 Fordham InT'L L. J. 823 (2004).

109. 15 U.S.C. $\$ \S 2310,2310(3)($ i)-(ii). The consumer can file a class action suit after agreeing to alternative dispute resolution when a court deems it necessary to establish the representative capacity of named plaintiffs. See id. at $\$ 2310(3)(d)$; $\S 2310(\mathrm{~d})$.

110. See, e.g., Paul D. Carrington, Self-Deregulation, 3 NEv. L.J. 259 (2002-2003). 
vention thus governs enforcement in the United States of arbitration awards made abroad and the enforcement abroad of awards issued in the United States in some consumer cases, and permits only limited challenges to their enforcement.

\section{B. Alternative Procedures}

Small claims courts and pre-litigation mediation are often available for consumer disputes in the United States, either by specific legal mandate or because many consumer claims are small and thus under the relatively low ceilings on amounts in controversy that limit the jurisdiction of such dispute resolution mechanisms. While systematic information is unavailable, these methods of dispute resolution are likely little-used in international consumer disputes because foreign defendants often cannot be effectively reached.

\section{Class Actions}

Class actions have been a major means for addressing consumer disputes in the United States (and are specifically provided for in the MMWA and some states' laws) although recent reforms have made such suits more difficult, particularly in federal courts. The general law of class actions extends to transnational consumer cases. The requirements for a class action (which vary somewhat between federal and state courts and across state courts) include: numerosity (that the class be of appropriate size, large enough to warrant departure from ordinary litigation but not unmanageably large); commonality (of questions of law or fact among the class members' claims); typicality (that the claims of the class representative be typical of those of the class); and adequacy (that the class representative be able to represent the interests of the plaintiff class adequately). In federal class action litigation, class certification requires further showing that class action would be a better method of adjudication along one or more of several dimensions. ${ }^{111}$

Federal and other class action rules do not have specific provisions for international consumer cases, but consumer cases involving foreign claimants can raise significant problems of commonality and typicality. Concerns about the complexity, and therefore manageability, of litigation and enforceability of a U.S. class action judgment abroad in transnational consumer cases can raise concerns that also provide grounds for determining that class litigation would not be superior or appropriate. ${ }^{112}$ Some state Unfair and Deceptive Acts and Practices (UDAP) laws prohibit class actions.

111. Fed. R. Crv. P. 23(a)-(b).

112. Jonathan K. Youngwood, Class Action Lawsuits Involving Foreign Claimants, 786 PLI/Lit 117 (2008). 


\section{International Cooperation by Administrative Authorities}

Pursuit of international cooperation by U.S. authorities in consumer protection cases takes several forms and is scattered across many entities. As in other cases of civil litigation, enforcement of U.S. judgments abroad in consumer protection cases is handled with much of the responsibility left to the parties and with Hague Convention procedures on the service of judgments (through designated central authorities in each country) applying in cases where the relevant foreign jurisdiction is a party to the convention. The same is true in the obverse case, where the question is one of enforcing a foreign judgment in U.S. courts in a transnational consumer rights case.

U.S. regulatory agencies with mandates extending to consumer protection work cooperatively with foreign governments. Enforcement actions by the FTC and other agencies such as the FDA and the CPSC sometimes entail collaboration with foreign government agencies when the targeted behavior includes activities abroad.

Internet transactions have brought increases in transnational deceptive trade practices cases. FTC authority to cooperate with foreign enforcement agencies in consumer protection e-commerce cases was clarified and expanded by the 2006 U.S. SAFEWEB Act. ${ }^{113}$ The Act authorizes the FTC to provide confidential information to, require reciprocal cooperation from, and engage in other forms of cooperation with foreign authorities, and to retain counsel to pursue cases abroad in international consumer fraud and deception cases. The Act also gives the FTC authority to conduct investigations and maintain confidentiality in such cases to facilitate cooperation with foreign law enforcement agencies.

U.S. agencies with responsibility for consumer protection cooperate with foreign counterparts to establish quality standards, inspection, compliance, and certification programs and, sometimes, to provide technical assistance and training to countries that export consumer goods, food products and pharmaceuticals to the United States. Sometimes such arrangements take the form of formal bilateral arrangements, such as the U.S.-China MOAs on food, drugs and medical devices (see Section VI). ${ }^{114}$

Much international cooperation is more informal or aspirational. For example, the International Consumer Protection and Enforcement Network (ICPEN), which includes the U.S.'s and more than thirty other countries' trade practices enforcement agencies, seeks to

113. SAFE Web ACT, Pub. L. No. 109-455, 120 Stat. 3372 (2006), amending 15 U.S.C. $\$ \$ 41$ et. seq. See also Summary of the U.S. Safe Web Act, http://www.ftc.gov/ reports/usaafeweb/Summary\%20of\%20US\%20SAFE\%20WEB\%20ACT.pdf (Nov. 5, 2009).

114. See also David Zaring, Three Challenges for Regulatory Networks, 43 InT'L LAw. 211 (2009) (discussing consumer protection as an area of cooperation among transnational "regulatory networks"). 
promote: gathering and sharing of information concerning consumer protection issues (including legislation and enforcement policies and practices), addressing cross-border violation of consumer protection laws, facilitating cross-border remedies, promoting enforcement of consumer protection laws, and encouraging wider cooperation among consumer protection enforcement organs. ICPEN has established mechanisms for consumer complaints about online international transactions and a collaborative database to aid member states' enforcement agencies. ${ }^{115}$

The CPSC participates, along with counterpart government agencies, business interests, law firms, and academics, in the International Consumer Product Health and Safety Organization (ICPSO). ICPHSO was founded in 1993 to address health and safety issues with consumer products that are marketed internationally. ${ }^{\mathbf{1 1 6}}$

The United States also participates in Organization for Economic Cooperation and Development (OECD) efforts to address transnational consumer protection issues. The OECD's Guidelines for Protecting Consumers from Fraudulent and Deceptive Commercial Practices Across Borders state that member countries recognize that fraudulent and deceptive practices undermine markets and harm consumers, businesses and states. The OECD seeks to advance cooperation among member states to combat cross-border fraudulent and deceptive commercial practices, improve information sharing, enhance cooperation among investigative agencies and between agencies and private sector entities, and provide effective remedies. The OECD Guidelines encourage member states to share information to facilitate identification of those involved in fraudulent and deceptive practices and to use online tools and databases to alert consumers to pending investigations and cases. ${ }^{117}$

\section{Chinese Lessons: Implications of Dangerous PRC Exports FOR U.S. Legal Approaches to Transnational Consumer Protection Problems}

Imports from China, including defective manufactured products, counterfeit goods and pharmaceuticals and tainted food and drugs, have become a significant source of harm to consumers in the United States. ${ }^{118}$ Lead-tainted toys and melamine-poisoned pet food are two of the more famous among many recent examples. The problems

115. See http://www.icpen.org/.

116. See Horvath, supra note 25 , at 741 .

117. OECD Guidelines for Protecting Consumers from Fraudulent and Deceptive Commercial Practices Across Borders 8-14 (2003).

118. The U.S. annually imports more than $\$ 300$ billion in goods from China. China is the U.S.'s largest source of manufactured imports, primarily consumer goods. China is by far the largest source of counterfeit goods identified by the U.S. Customs Service. 
posed by Chinese imports in the United States reflect the challenges of economic globalization, worldwide chains of production and the liberalized trading regime (which has expanded with China's WTO accession) and investment measures (including foreign investment treaties and Chinese and other host country laws designed to attract export-oriented foreign investment) that have facilitated such economic changes.

\section{A. Limits of Consumer Litigation against Chinese Producers}

The ordinary remedies available to consumers in U.S. law are comparatively ineffective in addressing the large and growing share of harms that come from Chinese (and other) imports. Chinese producers of adulterated, dangerous, or fake items are often beyond the effective reach of U.S. consumer litigation. Chinese firms relatively rarely sell directly into U.S. markets. Typically, they produce on a contract basis for foreign firms or produce and export in collaboration with a foreign partner in a joint venture enterprise that is a Chinese legal person. Long, complicated, and shifting supply chains in China mean that the source of danger often cannot be identified. The problem is still worse with producers of illegal fakes.

Discovery in China for litigation in the United States faces formidable barriers, particularly where parties seek to take depositions in China. Enforcement of U.S. court judgments in consumer protection cases does not yet occur in China. A very large portion of the offending producers of finished goods, inputs, foodstuffs, and fake goods in China are very small or very thinly capitalized and therefore judgment proof.

To the extent that Chinese law would govern cases involving Chinese exports, U.S. consumer plaintiffs face additional difficulties. Relevant Chinese law is changing rapidly and remains more dissimilar to U.S. laws relevant to consumer protection-and generally less protective of consumers - than do the laws of many major U.S. trading partners. For example, the effective date of China's first general tort statute is July 2010 , and standards for safe products in many sectors are much lower than under U.S. law.

\section{B. Unilateral U.S. Regulatory Measures}

Some unilateral U.S. efforts have sought to address specific problems for U.S. consumer safety posed by imports from China. Partly in response to lead-tainted and other dangerous Chinese toys,

The discussion in this section is drawn from Elizabeth Trujillo, From Here to Beijing: Public/Private Overlaps in Trade and Their Effects on U.S. Law, 40 CHI. Loy. L. J. 691 (2009) and Jacques deLisle, The Other China Trade Deficit: Export Safety Problems and Responses in IMPORT SAFETY: REgulatory Governance IN THE GLOBAL Economy (Cary Coglianese, Adam M. Finkel and David Zaring eds. 2009). 
Congress enacted the Consumer Product Safety Improvement Act. ${ }^{119}$ The Act expands the CPSC's authority and sets tougher limits, including on lead in toys. It directs the CPSC to require, from every manufacturer of covered products, certification that each product has passed a "reasonable testing program" and complies with "all rules, bans, standards, or regulations applicable to the product" under the Act or other laws enforced by the CPSC. The Act authorizes the CPSC to disclose discovered defects to U.S. and foreign government agencies. Congress has considered several other bills and U.S. agencies have considered or pursued regulations and administrative measures to address dangerous Chinese imports, especially after the product safety scandals of 2007-2008.

Such unilateral U.S. responses face significant limits. Zealous implementation or greatly enhanced restrictions that appear to target China risk escalating chronic bilateral trade frictions and Chinese retaliation on issues important to the United States. (Tellingly, U.S. criticisms of substandard and harmful Chinese products often have triggered sharp rebukes and denials from official and quasi-official PRC sources.) Influential U.S. constituencies-including companies investing in and exporting from China, supporters of free trade and others-sometimes oppose restrictive measures. Such domestic and international political considerations may leave little room for attention to consumer protection issues and advocates.

Some U.S. restrictions on Chinese exports are difficult to implement absent more robust cooperation from Chinese authorities than has been forthcoming. The resources available to U.S. agencies have been modest compared to the scale of the task. WTO rules limit the U.S.'s choice of regulatory means. Import-restricting measures to protect public health and safety are permissible, but they must have adequate scientific foundation and may impose only limited and nondiscriminatory restrictions on trade. ${ }^{120}$

\section{Bilateral U.S.-China Cooperation}

In 2007, the United States and China entered into Memoranda of Agreement on food and feed and drugs and medical devices and a Memorandum of Understanding on Consumer Protection Matters. ${ }^{121}$ In the MOAs, China pledged to require manufacturers of exports to

119. See P.L. 110-314 (Aug. 2008).

120. See Final Act Embodying the Results of the Uruguay Round of Multilateral Trade Negotiations, Technical Barriers to the Trade Agreement, Apr. 15, 1994, WTO Agreement, Annex 1A; Final Act Embodying the Results of the Uruguay Round of Multilateral Trade Negotiations, Sanitary and Phytosanitary Measures Agreement, Apr. 15, 1994, WTO Agreement, Annex 1A.

121. U.S. Department of Health and Human Services, New Agreement Will Enhance the Safety of Drugs and Medical Devices Imported from the People's Republic of China. (Dec. 11, 2007); Memorandum of Understanding on Consumer Protection Matters Between the State Administration for Industry and Commerce of the People's 
register and receive certification from Chinese government organs, to increase regulatory transparency, information sharing, and harmonization with international standards, and to allow greater inspections and strengthen quality regulation of early-stage inputs to assure compliance with U.S. import quality standards. Washington undertook to provide technical assistance and training to support such efforts. In the MOU, the two sides made commitments, including ones to follow OECD and ICPEN principles and to increase cooperation in exchanging views and information on consumer protection issues, laws and regulations, conducting training of consumer protection personnel, and exploring possible visits, seminars and workshops on consumer protection issues.

Such agreements promise only limited progress toward the energetic bilateral cooperation that might effectively address consumer protection problems associated with Chinese exports. The agreements have been general, included notable limiting language (as, for example, in the consumer protection MOU's promise to respect each other's domestic laws) and created no significant internationally legally binding obligations.

\section{U.S. Litigation against U.S. Defendants}

One of the most promising and rapidly emerging means for addressing consumer protection issues arising from Chinese exports relies on suits under U.S. law, brought in U.S. courts, against defendants present in the United States. ${ }^{122}$ Claims invoking the U.S.'s robust legal regime for defective products provide the most significant examples. Class actions, consolidated multidistrict litigation, and individual cases have proceeded in U.S. courts, primarily against U.S. defendants, over Chinese-produced pet food, toys, drywall, heparin, and other products. Given the obstacles foreign parties face in suing and enforcing judgments in China, U.S. defendants cannot count on Chinese parties for indemnification or contribution. With U.S. importers, owners, or co-venturers in China-based manufacturing operations thus facing the principal risks of liability, they have powerful incentives to increase monitoring of suppliers and partners and to demand and implement improvement of quality control in China.

Where efforts to reduce defect rates and danger from Chinese producers prove ineffective or costly, U.S. purchasers and investors facing legal liability at home will have incentives to shift, or threaten

Republic of China and the Federal Trade Commission of the United States of America (Jun. 12, 2007).

122. See e.g. In re Thomas Trains Paint Litig., No. 07 C 3514, 2007 WL 2667851 (N.D. Ill. Aug. 28, 2007) (class action, on behalf of consumers who purchase led painttainted toys produced in China, against U.S. manufacturer with investment in production operations in China and U.S. distributor). 
to shift, production elsewhere. Such moves would threaten Chinese export industries, which have long fueled China's growth and which, with respect to higher value-added exports, figure prominently in China's strategy for future growth by transition to a higher tech economy. This threat, in turn, can give Chinese authorities and enterprises unprecedented incentives to improve the laws and enforcement mechanisms that matter for the quality and safety of exports. Such developments could enhance meaningfully the protection of consumers and consumer interests in the United States. 